Illinois State University

ISU ReD: Research and eData

Faculty Publications - Finance, Insurance, and

Law

Finance, Insurance, and Law

2013

\title{
The Year-end Effect in Money Market Yields: Beyond One Month and Beyond the Crisis
}

Vladimir Kotomin

Illinois State University, vkotomi@ilstu.edu

Follow this and additional works at: https://ir.library.illinoisstate.edu/fpfil

Part of the Finance and Financial Management Commons

\section{Recommended Citation}

Kotomin, Vladimir, "The Year-end Effect in Money Market Yields: Beyond One Month and Beyond the Crisis" (2013). Faculty Publications - Finance, Insurance, and Law. 8.

https://ir.library.illinoisstate.edu/fpfil/8

This Article is brought to you for free and open access by the Finance, Insurance, and Law at ISU ReD: Research and eData. It has been accepted for inclusion in Faculty Publications - Finance, Insurance, and Law by an authorized administrator of ISU ReD: Research and eData. For more information, please contact ISUReD@ilstu.edu. 


\title{
THE YEAR-END EFFECT IN MONEY MARKET YIELDS: BEYOND ONE MONTH AND BEYOND THE CRISIS
}

\author{
Vladimir Kotomin \\ Illinois State University
}

Department of Finance, Insurance \& Law, College of Business, Illinois State University, Campus Box 5480, Normal, IL 61790-5480, USA, email vkotomi@ilstu.edu.

The author would like to thank the coeditor Drew Winters, the associate editor Tom Lindley, and the referee Stan Smith. 


\begin{abstract}
U.S. money market yields up to one month have shown changes consistent with year-end liquidity preferences. I find that three- and six-month negotiable certificate of deposit (CD), Eurodollar deposit (ED), and banker's acceptance (BA) yields are also affected by year-end liquidity preferences. Two- and three-month financial commercial paper (CP) yield changes are less pronounced. Banks - CD, ED, and BA issuers - have increased year-end liquidity needs, unlike finance companies - predominant CP issuers. The yearend effect disappears after the 2007-2008 crisis as depositories' cash holdings increase. $\mathrm{CD}$, ED, and $\mathrm{CP}$ yields diverge post-crisis, suggesting that investors no longer consider them close substitutes.
\end{abstract}

\title{
JEL Classification: G01, G12, G21
}




\section{Introduction}

Standard explanations for the term structure of interest rates include: (1) expectations theory, (2) liquidity preference theory, and (3) market segmentation theory with its corollary of preferred habitats. Modigliani and Sutch (1966) developed the preferred habitat theory to explain twists in the term structure of interest rates observed during the Kennedy Administration. Later, Roll (1970, p.38) states that “(p)references for certain maturities occur because fixed-payment securities are used as hedges against the payment streams of assets or liabilities that must be held in the course of business but which entail risk of interest rate fluctuations that businessmen do not care to incur." Ogden (1987) further notes that cash payment streams concentrate around the turn-of-themonth with the largest concentration at the turn-of-the-year.

Griffiths and Winters (1997) find that the yields of term repurchase agreements (repos) with maturities up to one month increase during the two days before the instrument's maturity starts spanning the end of the year, remain high through the thirdto-last trading day of the year, and decline to "normal" levels on the last two days of the year. Griffiths and Winters (2005) find similar yield change patterns in one-month commercial paper, as well as bankers' acceptances, negotiable certificates of deposit, Eurodollar deposits, and U.S. dollar LIBOR. They argue that this effect is caused by investors with known year-end cash obligations demanding money market instruments that mature prior to their cash obligation dates (which need not coincide with the last day of the year) in order to meet the obligations and dub it the year-end preferred habitat for liquidity. Kotomin, Smith and Winters (2008) extend Griffiths and Winters (2005) and find patterns consistent with the year-end preferred habitat for liquidity in one-week and 
one-month LIBOR for the major world currencies (in addition to U.S. dollar) - Yen, Euro, German Mark, and Swiss Franc.

I examine the behavior of yields of four classes of money market instruments that represent unsecured liabilities of U.S. financial institutions - negotiable certificates of deposits (CDs), Eurodollar deposits (EDs), banker's acceptances (BAs), and financial commercial paper (CP) - before, during, and after the financial crisis of 2007-2008. Before the crisis, $\mathrm{CD}, \mathrm{ED}$, and BA yields in maturities up to six months exhibit behavior consistent with a year-end preferred habitat for liquidity, while one-month, two-month, and three-month financial CP yield change patterns are similar but less pronounced, sometimes lacking statistical significance. It is likely related to the fact that CDs, EDs, and BAs are all liabilities of commercial banks, while financial CP issuers are dominated by captive finance companies. Commercial banks have an increased need for funds prior to the end of the year, driven by their customers' year-end preferences for liquidity (Kotomin and Winters 2006), while finance companies are likely to have lower liquidity needs and more flexibility in choosing maturities of their short-term debt prior to the end of the year. After the financial crisis, the year-end effect is no longer observed. The likely reason is that in the wake of the $2007-2008$ crisis, U.S. financial institutions, especially banks, increased holdings of cash so much that they easily meet seasonal liquidity needs. CD, ED, and CP yields diverge during and after the financial crisis of 2007-2008, indicating that investors no longer view these instruments as close substitutes. 


\section{Calendar Timing Effects in the Money Market Instruments}

Tax-loss selling and window dressing are routinely offered as explanations for the turn-of-the-year effect in equities. Tax-loss selling does not apply to money market instruments because, absent default, money market instruments most often provide gains, and any realized losses caused by yield increases are small due to low sensitivity of prices to interest rates. Musto (1997) offers flight-from-risk window dressing as an explanation for the higher U.S. commercial paper rates observed at the year-end. Flightfrom-risk window dressing is essentially an attempt by a financial institution to mislead investors and/or regulators by temporarily reducing riskiness of assets (e.g., by investing more in safer assets) prior to disclosure dates. Because window dressing is based on disclosure requirements, any effect caused by window dressing must span disclosure dates. Griffiths and Winters $(1997,2005)$ show that the higher year-end rates in the U.S. money market do not persist across the year-end disclosure date and offer the year-end preferred habitat for liquidity to explain the observed rate pattern.

A preferred habitat for liquidity is based on investors' preferences for instruments that mature before their cash obligation dates, so the funds are available to the investor to cover known cash obligations. Ogden (1987) shows that large amounts of known cash obligations cluster around the year-end, and Griffiths and Winters $(1997,2005)$ note that these obligations need not align with the last trading day of the year. Thus, investors (lenders) with year-end preferences for liquidity withdraw from the money markets when the instruments' maturity spans their cash obligation dates, which results in lower demand and higher yields for such securities. Later, investors return to the instruments they exited previously, driving rates back down to normal, with the rate decline 
beginning before the year-end disclosure date. Specifically, Griffiths and Winters (2005) report that various one-month private-issue U.S. money market instruments' yields increase on the two days before the instrument's maturity starts spanning the year-end (the last two days of November for a one-month maturity), remain at elevated levels throughout the third-to-last trading day of the year, and decline back to "normal" levels starting on the second-to-last trading day of the year. This pattern is consistent with investors wishing to retrieve their cash prior to the last two days of the year to pay cash obligations. Thus, to support a preferred habitat for liquidity, rates must increase before the instrument's maturity begins spanning year-end cash obligation dates, remain high through the cash obligation dates, and return to normal levels after the cash obligation dates pass.

The financial instruments studied - negotiable certificates of deposit, Eurodollar deposits, bankers' acceptances, and financial commercial paper - are all unsecured liabilities of private U.S. financial institutions. Their yields must therefore include the risk-free rate, a term premium, a default premium, and a liquidity premium. Negotiable certificates of deposit (CDs) are time deposits issued by depository institutions (mostly banks) that are transferrable. That is, they can be traded in the secondary market before maturity. Most negotiable CDs have denominations of $\$ 1$ million or more; smaller denominations are not as marketable and require higher yields. Because negotiable CD issue size exceeds the deposit insurance limit in the U.S., their yields reflect the current level of short-term rates, as well as issuing banks' creditworthiness and size (larger banks are able to offer lower yields on their CDs since they may be perceived as better diversified and/or too big to fail). 
Eurodollar deposits (EDs) are dollar-denominated time deposits held outside of the U.S. Non-personal time deposits (which include both negotiable CDs and EDs) are not subject to reserve requirements imposed on depository institutions by the Federal Reserve. Therefore, CDs and EDs may be close substitutes from the viewpoint of large, sophisticated U.S. banks that have access to international money markets.

Banker's acceptances (BAs), unlike CDs or EDs, originate from transactions of banks' clients, usually in international trade, as opposed to being created from activities of the banks themselves. The following is a simplistic example of how BAs work. An importer of goods is not granted credit by an exporter and turns to its bank. The bank provides credit to the importer, who draws a time draft and agrees to pay the bank the face value of the draft by its maturity. The bank stamps the draft "accepted", discounts it, and pays the importer the discounted value, which is used to purchase the goods. The bank may hold the acceptance in its portfolio or sell it at a discount to face value in the money market. At maturity, the importer pays the face value of the loan to its bank. Because BAs are preauthorized by letters of credit, if the importer defaults, the accepting bank makes the payment of the face value of the acceptance to the holder (unless it holds the acceptance itself). BAs have fallen out of active use by the end of the 1990s, and the Fed stopped reporting BA rates in 2000. Cyree, Lindley, and Winters (2007) find that BAs retained high liquidity even after they stopped playing a significant role in the U.S. money markets.

Commercial paper (CP) is short-term debt of private corporations with maturities between one and 270 days. I collect rates for $\mathrm{CP}$ issued by financial institutions that is not asset-backed (so called financial CP). In the case of the banking industry, $\mathrm{CP}$ is issued at 
the bank holding company level rather than at the individual bank level. However, the largest issuers of financial CP (as a group) are captive finance companies such as GE Capital or Caterpillar Financial.

The financial crisis of 2007-2008 had a profound impact on the U.S. financial system in general and the money markets in particular. Large losses and failures of some financial institutions, bailouts of specific institutions and the entire financial system, and unprecedented measures taken by the Fed, including the zero interest-rate policy and paying interest on bank reserves, all made U.S. financial institutions more risk averse and/or more willing to hold cash. Therefore, the calendar effects studied herein may have changed (at least temporarily) due to the crisis. I investigate the differences in calendartime effects in the money market yields before, during, and after the crisis.

\section{Data and Methods}

Data

The primary data are daily yields of private-issue U.S. money market instruments: negotiable certificates of deposit (CDs), Eurodollar deposits (EDs), banker's acceptances (BAs), and financial commercial paper (CP). All of the data come from the Federal Reserve's Release H.15 - Selected Interest Rates. The CD and ED yields are available for one-, three-, and six-month maturities, financial CP yields - for one-, two-, and threemonth maturities, and BA yields - for three- and six-month maturities. CD rates are averages of dealer offering rates on nationally traded CDs (i.e., secondary market data). BA rates represent yields for acceptances of highest-rated money center banks. ED yields 
are computed from brokered transaction data collected by the Fed. ${ }^{1} \mathrm{CP}$ rates are computed based on CP sales by dealers as well as direct sales by issuers to investors (i.e., CP rates are offer-side rates). The study period is from the beginning of 1991 through the end of 2011, subject to data availability. Financial CP yields are available from the beginning of $1997 .{ }^{2}$ The Fed stopped collecting and reporting BA yields in the middle of 2000, thus I use BA yields through the end of 1999. The sample begins in 1991 because in December 1990 Eurodollar deposits stopped being a subject to the reserve requirements imposed by the Fed on depository institutions.

Three-month and six-month secondary market U.S. Treasury bill (T-bill) yields are collected to use as controls for the general level of interest rates in the U.S. money markets. ${ }^{3}$ Using T-bills of the same maturity as the private-issue instruments studied would be ideal; however, the one-month (or, more accurately, four-week) T-bills have been issued only since July 31,2001 . Table 1 contains descriptive statistics for the study period, 1991-2011. PH stands for preferred habitat and covers the period of increased yields identified by Griffiths and Winters $(1997,2005)$ - from the second-to-last day on which the instrument is both issued and matures before the end of the year (e.g., the second-to-last trading day of September for the three-month maturity) through the thirdto-last trading day of the year. Non-PH covers all the other days. Consistent with a yearend preferred habitat for liquidity, higher spreads over T-bills are observed in the periods

\footnotetext{
${ }^{1}$ Another potential source of Eurodollar yields is the London Interbank Offer Rate (LIBOR) reported by the British Bankers Association (BBA). I use the Fed data because LIBOR has two disadvantages: (1) it represents an average of quotes, not actual transactions, and (2) it is based on a survey of only 16 banks, with the extreme quartiles dropped from the computation of the rate.

${ }^{2}$ The Fed changed the collection process of CP yields in 1997. Instead of reporting yields of dealer-placed and directly placed $\mathrm{CP}$, it started reporting $\mathrm{CP}$ yields by issuer types: financial, nonfinancial, and assetbacked.

${ }^{3}$ Using constant maturity T-bill yields instead of secondary market T-bill yields does not sensibly affect the results.
} 
covered by $\mathrm{PH}$ in all four classes of private-issue instruments. Note that the T-bill yield being different in the $\mathrm{PH}$ versus the non-PH period is due to T-bill yields declining sharply over the crisis period, and not due to the reverse year-end preferred habitat effect in T-bills. The difference is much smaller and not statistically significant when tested over the pre-crisis period, 1991-2006. All the spreads of private-issue instruments over Tbills in the next-to-last column remain statistically different in the $\mathrm{PH}$ versus the non-PH period at better than the $1 \%$ level when tested over the pre-crisis period.

\section{[INSERT TABLE 1 HERE]}

\section{Methods}

As discussed, the interest rate regularity for a preferred habitat for liquidity is: rates increasing when instruments' maturity spans cash obligation dates, remaining abnormally high across the cash obligation dates, and declining back to normal after cash obligation dates pass. The methods are similar in spirit to those of Griffiths and Winters (1997, 2005) and Kotomin, Smith and Winters (2008). For each instrument and maturity, I estimate the following OLS with the White's (1980) adjustment for heteroskedasticity:

$$
\begin{aligned}
& \Delta \mathrm{R}_{\mathrm{t}}=\alpha_{0}+\alpha_{1}\left(\Delta \mathrm{R}_{\mathrm{t}-1}\right)+\alpha_{2}\left(\Delta \mathrm{TB}_{\mathrm{t}}\right)+\alpha_{3} \mathrm{BYCR}+\alpha_{4} \mathrm{AYCR}+\alpha_{5} \mathrm{BYEND}+\alpha_{6} \mathrm{AYEND} \\
& +\mathrm{b}_{0} \mathrm{Yrs}_{0708}+\mathrm{b}_{1}\left(\Delta \mathrm{R}_{\mathrm{t}-1}\right) \mathrm{Yrs} 0708+\mathrm{b}_{2}\left(\Delta \mathrm{TB}_{\mathrm{t}}\right) \mathrm{Yrs} 0708+\mathrm{b}_{3}(\mathrm{BYCR}) \mathrm{Yrs} 0708 \\
& +\mathrm{b}_{4}(\mathrm{AYCR}) \mathrm{Yrs} 0708+\mathrm{b}_{5}(\mathrm{BYEND}) \mathrm{Yrs} 0708+\mathrm{b}_{6}(\mathrm{AYEND}) \mathrm{Yrs} 0708 \\
& +\mathrm{c}_{0} \mathrm{Yrs} 0911+\mathrm{c}_{1}\left(\Delta \mathrm{R}_{\mathrm{t}-1}\right) \mathrm{Yrs} 0911+\mathrm{c}_{2}\left(\Delta \mathrm{TB}_{\mathrm{t}}\right) \mathrm{Yrs} 0911+\mathrm{c}_{3}(\mathrm{BYCR}) \mathrm{Yrs} 0911 \\
& +\mathrm{c}_{4}(\mathrm{AYCR}) \mathrm{Yrs} 0911+\mathrm{c}_{5}(\mathrm{BYEND}) \mathrm{Yrs} 0911+\mathrm{c}_{6}(\mathrm{AYEND}) \mathrm{Yrs} 0911+\varepsilon_{\mathrm{t}} \\
& \text { where: }
\end{aligned}
$$


$\Delta R_{t} \quad$ is the daily change (i.e., the first difference) in the yield of CD, ED, BA, or financial $\mathrm{CP}$ of given maturity, in basis points,

$\Delta \mathrm{R}_{\mathrm{t}-1} \quad$ is the first lag of the dependent variable,

$\Delta \mathrm{TB}_{\mathrm{t}} \quad$ is the daily change in the T-bill secondary market rate of the three- or sixmonth maturity (whichever is closer to the maturity of the instrument being studied), in basis points,

BYCR is a dummy variable that equals 1 on the two trading days before the instrument's maturity starts to span the end of the year and 0 otherwise (BYCR stands for before, year, and crossed),

AYCR is a dummy variable that equals 1 on the two trading days after the instrument's maturity starts to span the end of the year and 0 otherwise (AYCR stands for after, year, and crossed),

BYEND is a dummy variable that equals 1 on the last two trading days of the year and 0 otherwise,

AYEND is a dummy variable that equals 1 on the first two trading days of the year and 0 otherwise,

Yrs0708 is a dummy variable that equals 1 on all days in 2007 and 2008 (the crisis period),

Yrs0911 is a dummy variable that equals 1 on all days in 2009 through 2011 (the post-crisis period).

The time subscripts for the dummy variables have been suppressed.

Specifying the dependent variable as a first difference in rates allows the

regression coefficients to be interpreted as daily changes in the yield in basis points. Also, using a change in the yield instead of a level is preferred because all the rate series are likely nonstationary (the null of no unit root is rejected for all series at high levels of confidence), while all the first difference series are likely stationary (the null of no unit root is not rejected for any series). The lagged dependent variable is included to address 
autocorrelation in interest rate changes. ${ }^{4}$ The first four dummy variables are designed to measure the effects related to the year-end liquidity preferences. The last two dummy variables capture the crisis (2007-2008) and the post-crisis (2009-2011) periods. ${ }^{5}$ Each of these two variables is interacted with all other independent variables to determine whether the relations between yields of money market instruments and the explanatory variables changed during and after the crisis. The estimated coefficients of these variables ( $b$ 's and $c$ 's) are interpreted as the differences from their pre-crisis counterparts ( $\alpha$ 's).

The regressions capture the rate changes at break points for specific maturities but not the persistence of abnormal yields between these changes. To address this concern, I plot average daily spreads calculated as follows. First, spreads between the yields of the studied private instruments and T-bill yields are calculated for each day in the sample. Some low-volatility observations have been deleted or inserted to ensure that every year has exactly 250 days (it was done only for the purpose of constructing the plots). Second, the average spreads are calculated for each day from 1 to 250. E.g., the spreads on Day 15 every year are used to calculate the average spread for Day 15.

\footnotetext{
${ }^{4}$ The estimation output of Equation (1) is not sensitive to the way the dependent variable is specified (e.g., a change in the level, a spread over T-bill yield, or a change in the spread), nor to the presence or absence of the lagged dependent variable and T-bill yield changes on the right-hand side. To make sure that Equation (1) results are not driven by changes in the general level of short-term interest rates (i.e., T-bill yield changes), similar regressions have been run with daily changes in the term spreads between the yields of the same instruments as dependent variables (i.e., one-three, one-six, and three-six month yield spreads). The results are not affected.

${ }^{5}$ The crisis in the money markets started in the summer of 2007; only lower-quality instruments were significantly affected at that time. After the Lehman Brother bankruptcy in September 2008, however, short-term liabilities of even highly-rate financial institutions experienced spikes in yields. By the beginning of 2009, the money market rates in the U.S. mostly stabilized and volatility subsided. See, e.g., Griffiths, Kotomin, and Winters (2011) for a study of the U.S. commercial paper markets during the crisis.
} 


\section{Empirical Results}

Average daily spread plots and regressions constitute the primary analysis of the year-end effects. The plots are used to determine if the spreads behave differently during periods preceding the year-end in which heightened demand for liquidity is likely, while the regressions test if statistically significant rate changes occur at the break points.

\section{Spread Plots}

Panel A of Figure I plots the CD over T-bill average yield spreads in each maturity. The intrayear spread behavior in all three maturities is consistent with the yearend preferred habitat for liquidity in negotiable CD yields. The spreads are higher over the last one, three, and six month of the year (excluding the last two days) in the one-, three-, and six-month maturities, respectively. The pattern is the same as reported in previous research for maturities up to one month (Griffiths and Winters 1997, 2005; Kotomin, Smith, and Winters 2008); moreover, it appears to extend to maturities beyond one month.

\section{[INSERT FIGURE I HERE]}

Proceeding to Panel B of Figure I, very similar patterns of spread changes emerge for EDs. This is expected because CDs and EDs may be close substitutes for large U.S. banks with access to international money markets.

Panel C of Figure I plots intrayear average spreads for financial CP. The spread patterns for $\mathrm{CP}$ appear similar to the first two instruments, CDs and EDs. However, the CP-T-bill yield spread increases in panel $\mathrm{C}$ are less pronounced and not necessarily sustained through the entire period typically associated with year-end preferred habitats 
for liquidity. For example, the three-month $\mathrm{CP}$ yield goes up relative to T-bill yield a few days before the CP maturity starts spanning the year-end (the spread rises from 53bps on day 188 to 67bps on day 195) but this increase is not sustained for long - the spread falls to below 50bps by day 206. This result suggests less pressure on financial CP yields prior to year-ends compared with $\mathrm{CD}$ and $\mathrm{ED}$ yields (possible reasons are discussed in the next subsection).

Panel D of Figure I provides the plots for banker's acceptances. BA yield spreads over T-bills behave in a manner similar to CD and ED spreads - the increases occur at the PH break points and are sustained. While BAs may be a relatively close substitute for CDs and EDs, banks do not have as much control over the volume of BAs they originate.

The intrayear average spread patterns for CDs, EDs, and CP presented in Panels $\mathrm{A}, \mathrm{B}$, and C, respectively, are not due to the influence of the financial crisis or the postcrisis period. Similar spread patterns emerge when the sample is limited to the pre-crisis period, 1991-2006. The impact of the crisis on the relations among CD, ED, and financial $\mathrm{CP}$ yields is discussed later in the paper. ${ }^{6}$

\section{Regressions}

Table 2 reports the estimation output of Equation (1) for different instruments and maturities. Examining these results allows us to determine if the yield changes apparent from the spread plots are statistically significant. To make the discussion tractable, I first

\footnotetext{
${ }^{6}$ To make sure that the plotted changes in the spreads are not driven by changes in the general level of short-term interest rates (i.e., T-bill yield changes), I also plotted term spreads between the yields of the same instruments (i.e., one-three, one-six, and three-six month yield spreads). These plots also reveal patterns consistent with the year-end preferred habitat for liquidity. E.g., the one-three month CD spread falls in the end of September when the three-month yield goes up due to the year-end effect, then increases in the end of November by more than it had fallen as the one-month CD experiences the year-end effect, and finally goes down to "normal" levels in the last two days of the year. These plots are not presented in the interests of brevity.
} 
focus on the results for the pre-crisis period (denoted as the "base period" for each regression in the table) and then proceed to the crisis and post-crisis periods.

[INSERT TABLE 2 HERE]

\section{Pre-Crisis Period Results}

Panel A of Table 2 shows that the CD yields in all three maturities increase on the second-to-last and the last day on which the CD both is issued and matures before the end of the year (i.e., the coefficient of the BYCR dummy is positive and significant). Because the dependent variable is specified as a daily rate change and each of the four indicator variables of interest (BYCR, AYCR, BYEND, and AYEND) covers two consecutive days in each year, their estimated coefficients are interpreted as yield changes in basis points on each of the two consecutive days covered by the dummy. For example, in the case of the one-month maturity, the yield tends to increase by $12.7 \mathrm{bps}$ on each of the two trading days covered by the BYCR dummy (the last two trading days of November) and decrease by $7.9 \mathrm{bps}$ on each of the last two trading days of the year. The yield declines further by $2.4 \mathrm{bps}$ on each of the first two days of the next year. The finding for the onemonth maturity confirms a similar finding in Griffiths and Winters (2005). In addition, I

find similar patterns for the three-month (six-month) CD yields: the yields increase by 4.5 (3.0) basis points on each of the last two trading days of September (June) and decrease by $2.8(0.9)$ basis points on each of the last two trading days of the year. In the case of the three-month maturity, the yield continues to decline on the two days after the year-end. The $0.9 \mathrm{bps}$ decrease in the six-month yield on the last two days of the year is not statistically significant. 
Panel B of Table 2 has the regression output for Eurodollar deposits. The estimated parameters are slightly larger in magnitude than their CD counterparts from Panel A. This result is consistent with CDs and EDs being close substitutes. In addition to the one-month ED yield, which increases by 16bps on each of the last two trading days of November and falls by $7.5 \mathrm{bps}$ on each of the last two days of the year, three- and sixmonth ED yields also demonstrate statistically and economically significant changes at the break points: the three-month (six-month) ED yield goes up by 5.5bps (3bps) on each of the last two days of September (June) and goes down by $2.4 \mathrm{bps}$ (1.9bps) on each of the last two days of the year. It is expected that the shortest maturity (one month) has stronger year-end effects, because clarity regarding year-end cash obligations increases as the year-end approaches and because more investors start planning for the year-end. However, I find statistically and economically significant effects even in the yields of longer maturities, specifically, three- and six-month CD and ED yields, which is something not identified in prior studies.

Estimated yield changes for CDs and EDs being the largest across the four classes of instruments studied is consistent with CDs and EDs (especially EDs, given the largest and most statistically significant estimates) being marginal sources of funds for large, internationally active U.S. banks.

The regression output for changes in financial CP yields is in Panels C of Table 2. While the patterns are similar to those in CDs and EDs, there are several notable differences. First, the increase in the yields starts after the maturity of the instrument 
begins to span the end of the year (i.e., in the two days covered by the AYCR dummy). ${ }^{7}$

The yields do go down to "normal" levels promptly in the last two days of the year,

however. ${ }^{8}$ Second, statistical significance is lacking in the yield increases in two- and

three-month maturities, suggesting that these increases are too gradual to be captured by regression variables that cover only two consecutive days. (One cannot deny, however, that yield increases relative to T-bills are present: see Table 1 and Figure I.) The lack of sharp yield increases in maturities longer than one month is consistent with less pressure on financial $\mathrm{CP}$ yields for these maturities prior to the end of the year than on $\mathrm{CD}$ and $\mathrm{ED}$ yields. This lower pressure may be a result of several factors.

First, commercial banks tend to have increased liquidity needs prior to the end of the year, which is driven primarily by liquidity needs of their customers. Kotomin and Winters (2006) report that banks in the U.S. (in aggregate) experience large increases in demand deposits prior to the end of the year. These increases are consistent with bank customers preparing to disburse payments related to their year-end cash obligations. Kotomin, Smith, and Winters (forthcoming) show that the money flowing into transaction deposits prior to the year-end likely comes from non-transaction deposits and money market funds, as aggregate balances in these types of accounts fall prior to the end of the year. Kotomin and Winters (2006) show that banks respond to the changes in their deposit structure by increasing their holdings of liquid assets (cash and government securities). After the end of the year, the flow of funds is reversed: transaction deposit

\footnotetext{
${ }^{7}$ While the Fed Release H.15 labels the CP rates it reports as one-, two-, and three-month CP yields, the actual CP maturities are 30, 60, and 90 days, respectively. I do adjust the BYCR and AYCR dummies for CP to cover the break points for 30-, 60-, and 90-day maturities rather than for 1-, 2-, and 3-month ones. For consistency, however, I refer to $\mathrm{CP}$ as one-, two-, and three-month $\mathrm{CP}$ throughout the paper.

${ }^{8}$ The one-month CP results are in line with Griffiths and Winters (2005).
} 
balances fall, and non-transaction deposit and money fund balances increase. Since these changes in the deposit composition are predictable, banks may start preparing for the temporary year-end increase in liquidity needs in advance by issuing liabilities that will mature after the peak year-end liquidity needs. On the other hand, finance companies (the largest issuers of financial $\mathrm{CP}$ ), being non-depository institutions, may not face a large increase in the need for liquidity (or in uncertainty regarding liquidity needs) prior to the end of the year.

Second, CP issuers place their paper either directly with investors or through dealers; they cultivate relationships with their lenders or dealers. Issuers that place their paper directly may be able to negotiate the rates with lenders. As to dealer-placed paper, Stigum and Crescenzi (2007) note that dealers in the CP market work closely with their clients and value these relationships because being a client's dealer in the CP market often helps sell investment banking services to the client. ${ }^{9}$

Third, $\mathrm{CP}$ issuers that are non-banks may have more flexibility when it comes to choosing the maturity of the paper sold due to lower year-end liquidity needs or lower uncertainty regarding such needs. They work with lenders or dealers directly in deciding on the maturities of $\mathrm{CP}$ to be issued, ranging from one day to more than six months.

Panel D of Table 2 reports the estimated coefficients from running Equation (1) for BAs. The yield changes for 3-month and 6-month BAs are both consistent with the year-end preference for liquidity and comparable in magnitude with their CD and ED counterparts from Panels A and B. If a bank needs liquidity, it may sell BAs it has

\footnotetext{
${ }^{9}$ Starting in 2001, the Fed has reported volumes outstanding of directly- and dealer-placed commercial paper. Between 2001 and 2008, the proportion of financial CP placed directly was between $30 \%$ and 50\%, hovering just over the $30 \%$ mark most of the time. After the financial crisis, the proportion of directly placed paper has dramatically increased.
} 
originated in the secondary market, but the volume of BA originations depends on requests from the bank customers. BA issuance volume was not close to that of CDs or EDs even in the beginning of the study period when BAs were fairly common. Thus, BAs cannot be relied upon as a marginal source of funds for banks, while CDs and EDs can, and this is likely the reason why CDs and EDs exhibit the more dramatic yield and spread changes prior to the end of the year ${ }^{10}$. BA yield changes being consistent with preferred habitat for year-end liquidity is the result of different short-term bank liabilities being close substitutes of each other (Cyree, Lindley, and Winters 2007), not of BAs being a marginal source of funds for commercial banks.

\section{Crisis and Post-crisis Period Results}

There are several results worth discussing in this subsection. First, most yield changes show a positive correlation with Treasury bill yield changes prior to the crisis (1991-2006), indicating the yields moving together, and negative (or at least lower) correlation during the crisis (2007-2008) and often after the crisis (2009-2011), indicating the yields of T-bills and private instruments moving in opposite directions. For example, the coefficient of the T-bill change for the one-month $\mathrm{CD}$ rate change is 0.24 in the precrisis period, -0.33 during the crisis period (the sum of the coefficients 0.24 and -0.57 ), and 0.03 in the post-crisis period (the sum of 0.24 and -0.21 ). This is consistent with the flight to quality during the crisis.

Second, the year-end preferred habitat effect appears to be stronger during the crisis period for two of the three maturities in CDs and EDs, but the differences are not

\footnotetext{
${ }^{10}$ When estimated over the BA data period (1991-1999) or the financial CP data period (1997-2011), CD and ED yield changes are still larger in magnitude and/or more statistically significant than BA and CP yield changes over the respective periods (the results are not reported in the interests of brevity).
} 
statistically significant. Since the crisis period is only two years, each indicator variable of interest only covers four days in total; therefore, even statistically significant coefficients should be interpreted with caution.

Third, the year-end effect in CDs and EDs is completely eliminated after the crisis: the post-crisis coefficients of BYCR and BYEND are almost of the same magnitude but with signs opposite to their whole-sample counterparts'. For example, the 3-month ED whole-sample BYCR coefficient is 5.5bps, and the post-crisis one is -5.3bps. Adding the two coefficients together suggests practically no increase in the 3-month ED yields on the days prior to the three-month maturity starting to span the year-end in 20092011. This disappearance of the year-end effect in CD and ED yields is not surprising because banks in the U.S. have held extremely high amounts of excess reserves (by historical measures) starting in the fall of 2008. The aggregate excess reserves of U.S. depository institutions were $\$ 2$ bln in August 2008, \$59bln in September 2008, \$267bln in October 2008, and continued to grow afterwards, exceeding \$1trln in November 2009 and remaining above this mark through the end of 2011. ${ }^{11}$ Normally, banks would minimize their excess reserves and try to invest or lend the money and then borrow in the money markets (such as $\mathrm{CD}$ or ED markets) to cover any liquidity shortfalls, but the postcrisis combination of increased risk aversion, extremely low market interest rates, the Fed paying interest on bank reserves starting in October 2008, and decreased lending opportunities caused banks to hoard cash in amounts more than sufficient to cover the increased year-end liquidity needs. Future developments will determine whether the year-

\footnotetext{
${ }^{11}$ Federal Reserve Statistical Release H.3, "Aggregate Reserves of Depository Institutions and the Monetary Base".
} 
end effect will return to the money markets after the banking industry fully recovers from the consequences of the crisis and interest rates increase.

Lastly, financial CP does not experience statistically significant changes in the year-end effect in most cases during and after the crisis. However, recall that the precrisis effects in $\mathrm{CP}$ are often statistically insignificant as well. All the post-crisis coefficients in $\mathrm{CP}$ (both statistically significant and insignificant) are of signs opposite of their pre-crisis counterparts', consistent with the disappearance of the year-end effect.

\section{Substitutability of Money Market Instruments before and after the Crisis}

Private-issue unsecured money market instruments all share key fundamental characteristics - low default risk, high liquidity, and short term to maturity. Therefore, they may be viewed by investors as close substitutes and have similar yields. For example, Cyree, Lindley, and Winters (2007) report average yields of the same four classes of instruments - CDs, EDs, BAs, and financial CP - being close to each other over the period 1984 through 2000. High degree of substitutability also appears to be the case before the crisis in the data examined in the present study. Figure II plots the yields of three-month CDs, EDs, financial CP, and T-bills for the period 2006-2011. Before the crisis broke out in the money markets in the summer of 2007, the yields of the three classes of private instruments tracked each other very closely. However, private-issue money market instruments also have some credit (default) risk and liquidity risk. In a systemic crisis, a run by lenders is possible, and actually thought to have happened in the U.S. money markets after the Lehman Brothers bankruptcy in September 2008. Figure II shows that the yields of CDs, EDs, and financial initially diverged in mid-2007 when the 
crisis was first felt in the money markets and stayed separated through the end of 2007, then diverged again in March 2008 (after the Bear Stearns failure) and even more in September 2008 (after the Lehman failure). ED yields remained notably above CD and CP yields even after the worst of the crisis was over and all the rates seemingly settled to new, lower, levels. CD yields were notably above CP yields before May 2009 and again after May 2011.

\section{[INSERT FIGURE II HERE]}

For a more formal test of divergence of yields of the studied instruments, Table 3 presents the results of the equality-of-means tests for the pairs of instruments that have data available through the end of the sample for the pre-, during-, and post-crisis periods - before 2006, 2007-2008, and 2009-2011, respectively. In all pairs of instruments and maturities, the differences between yields were statistically indistinguishable from zero before the crisis and were significantly different from zero, most of them at better than the $1 \%$ level (based on p-values of two-tailed t-tests) during and after the crisis. This pattern of yield separation suggests that the U.S. money markets have become more segmented as a result of the crisis, and that investors no longer view different privateissue money market instruments as close substitutes of each other.

First, financial CP yields have been lowest during and after the crisis. It is likely at least partially due to the fact that significant amounts of financial CP were guaranteed by the FDIC's Temporary Liquidity Guarantee Program (TGLP) starting in October 2008 through the end of the data period (in spite of many institutions opting out of the Program 
by December 2008). ${ }^{12}$ Second, ED yields, which were equal to CD yields before the crisis, have been clearly higher than $\mathrm{CD}$ yields during and after the crisis. While the Fed does not report ED volume data, it is likely that the volume has declined after the crisis due to the U.S. banks' increase in excess reserves and decrease in lending. In this case, only a relatively small subset of banks that needed to borrow short-term funds after exhausting other sources would participate in the ED market, making EDs a truly marginal source of funds for a bank.

\section{[INSERT TABLE III HERE]}

\section{Conclusion}

Previous research finds increased yields or spreads in maturities of up to one month in various private-issue money market instruments in the U.S. (Griffiths and Winters 1997, 2005) and in LIBOR for major world currencies (Kotomin, Smith, and Winters 2008). This study's contribution is in the finding that U.S. private-issue money market instruments of longer maturities, specifically, three-month and six-month negotiable certificates of deposit (CDs), Eurodollar deposits (EDs), and banker's acceptances (BAs), also demonstrate yield changes consistent with the year-end preferred habitat for liquidity prior to the financial crisis of 2007-2008. Three- and six-month yields in these instruments increase before the instruments' maturity starts spanning the end of the year and return to normal levels in the last two trading days of the year. The yield changes of financial $\mathrm{CP}$ of maturities beyond one month, while generally consistent

\footnotetext{
12 The instruments guaranteed by the TGLP were dominated by financial commercial paper and mediumterm notes. Monthly debt issuance and type of instruments under the Program can be found at http://www.fdic.gov/regulations/resources/TLGP/reports.html (accessed June 23, 2012).
} 
with preferred habitats for year-end liquidity, are less pronounced than in CDs, EDs, and BAs, and sometimes lack statistical significance. Financial CP issuers are dominated by finance companies, while the other three instruments are liabilities of commercial banks. Commercial banks' liquidity needs are driven to a large extent by the liquidity needs of their depositors. Banks tend to see large increases in demand deposits (the most volatile category of deposits) prior to the end of the year, as depositors move money from less liquid deposit accounts and money market funds in order to make year-end cash disbursements (Kotomin, Smith, and Winters, forthcoming). Banks prepare for the yearend increase in liquidity needs by holding (borrowing) more liquidity (Kotomin and Winters 2006). Finance companies do not have deposits among their liabilities; consequently, they likely have lower liquidity needs at the year-end than banks.

In the three years after the financial crisis, 2009 through 2011, the year-end effects in CD and ED yields, which were both statistically and economically significant before the crisis, are no longer observed. It is consistent with increased holdings of cash assets by banks in the wake of the financial crisis and, consequently, reduced need to borrow in the money markets to cover liquidity shortages. $\mathrm{CD}, \mathrm{ED}$, and financial $\mathrm{CP}$ yields diverge during and after the crisis of 2007-2008, indicating that investors no longer consider these instruments close substitutes. 


\section{References}

Cyree, K. B., J. T. Lindley, and D. B. Winters, 2007, The effect of substitute assets on yields in financial markets, Financial Management 36, 27-47.

Griffiths, M. D., V. Kotomin, and D. B. Winters, 2011, The Fed and the 2007-2009 financial crisis: Treating a virus with antibiotics? Evidence from the commercial paper market, Financial Review 46, 541-567.

Griffiths, M. D., and D. B. Winters, 1997, On a preferred habitat for liquidity at the turnof-the-year: Evidence from the term-repo market, Journal of Financial Services Research 12, 21-38.

Griffiths, M.D., and D. B. Winters, 2005, The-turn-of-the-year in money markets: Tests of the risk-shifting window dressing and preferred habitat hypotheses, Journal of Business 78, 1337-1364.

Kotomin, V., S. D. Smith, and D. B. Winters, forthcoming, Interest-rate and calendartime effects in money market fund and bank deposit cash flows, Journal of Economics and Finance.

Kotomin, V., S. D. Smith, and D. B. Winters, 2008, Preferred habitat for liquidity in international short-term interest rates, Journal of Banking and Finance 32, 240250.

Kotomin, V., and D. B. Winters, 2006, Quarter-end effects in banks: Preferred habitat or window dressing? Journal of Financial Services Research 29, 61-82.

Modigliani, F., and Sutch, R., 1966, Innovations in interest rate policy, American Economic Review 56, 178-197.

Musto, D. K., 1997 Portfolio disclosures and year-end price shifts, Journal of Finance, $52,1563-1588$.

Ogden, J. P., 1987, The end of the month as a preferred habitat: A test of operational efficiency in the money market, Journal of Financial and Quantitative Analysis 22, 329-344.

Roll, R., 1970, The Behavior of Interest Rates: An Application of the Efficient Market Model to US Treasury Bills (Basic Books, New York, NY). 
Stigum, M., and A. Crescenzi, 2007, Stigum's Money Market (McGraw-Hill, New York, NY).

White, H., 1980, A heteroskedasticity-consistent covariance matrix estimator and a direct test for heteroskedasticity, Econometrica 48, 817-838. 
TABLE 1. Mean Yields and Spreads, 1991-2011.

\begin{tabular}{|l|c|c|c|c|c|c|c|}
\hline & \multirow{3}{*}{} & \multicolumn{3}{|c|}{ Mean Yields, \% } & \multicolumn{3}{c|}{ Mean Spreads over T-bills, bps. } \\
\cline { 3 - 8 } & Obs. & Sample & PH & Non-PH & Sample & PH & Non-PH \\
\hline 1-month CD & 5,236 & 3.63 & 3.65 & 3.63 & 37.2 & $56.9^{* * *}$ & 35.4 \\
3-month CD & 5,236 & 3.71 & 3.71 & 3.71 & 45.3 & $57.8^{* * *}$ & 41.2 \\
6-month CD & 5,236 & 3.82 & 3.80 & 3.84 & 44.9 & $48.3^{* * *}$ & 41.5 \\
\hline 1-month ED & 5,227 & 3.65 & 3.68 & 3.65 & 39.5 & $61.0^{* * *}$ & 37.5 \\
3-month ED & 5,228 & 3.76 & 3.77 & 3.76 & 50.3 & $64.1^{* * *}$ & 45.8 \\
6-month ED & 5,227 & 3.88 & 3.87 & 3.90 & 51.1 & $54.8^{* * *}$ & 47.4 \\
\hline 3-month BA & 2,252 & 4.92 & $4.99^{*}$ & 4.90 & 36.5 & $48.4^{* * *}$ & 32.6 \\
6-month BA & 2,252 & 4.96 & 4.98 & 4.95 & 27.9 & $32.1^{* * *}$ & 23.6 \\
\hline 1-month financial CP & 3,733 & 3.12 & 3.02 & 3.13 & 33.3 & $44.2^{* * *}$ & 32.4 \\
2-month financial CP & 3,700 & 3.17 & 3.28 & 3.15 & 36.1 & $42.5^{* * *}$ & 34.8 \\
3-month financial CP & 3,691 & 3.21 & 3.20 & 3.21 & 39.2 & $47.5^{* * *}$ & 36.6 \\
\hline 3-month T-bill & 5,236 & 3.26 & $3.13 * * *$ & 3.30 & \multicolumn{4}{|}{} \\
6-month T-bill & 5,236 & 3.37 & $3.32^{* *}$ & 3.42 & \multicolumn{3}{|}{}
\end{tabular}

Note: Descriptive statistics are for daily yields of negotiable certificates of deposit (CDs), Eurodollar deposits (EDs), banker's acceptances (BAs), financial commercial paper (CP), and T-bills, as well as spreads of the private securities' yields over T-bill yields. The sample period is 1991-2011 for CDs and EDs, 1991-1999 for BAs, and 1997-2011 for $\mathrm{CP}$. The spreads of one-, two-, and three-month yields are over the three-month T-bill yield; the spreads of six-month yields are over the six-month T-bill yield.

PH stands for preferred habitat and covers the period of increased yields identified by Griffiths and Winters $(1997,2005)$ - from the second-to-last day on which the instrument is both issued and matures before the end of the year (e.g., the second-to-last trading day of September for the three-month maturity) through the third-to-last trading day of the year. Non-PH covers all other days.

The asterisks in the PH columns indicate that the mean yield or spread during the yearend preferred habitat period $(\mathrm{PH})$ is statistically different from its counterpart on all other days (non-PH).

$* * *$ significant at the $1 \%$ level.

** significant at the 5\%, level.

* significant at the $10 \%$ level. 
TABLE 2. Regression Results.

Panel A. CD Rate Changes, 1991-2011, in bps.

\begin{tabular}{|c|c|c|c|c|c|c|c|c|c|}
\hline & \multicolumn{3}{|c|}{ 1-month } & \multicolumn{3}{|c|}{ 3-month } & \multicolumn{3}{|c|}{ 6-month } \\
\hline & \multirow{2}{*}{$\begin{array}{l}\text { Base Period } \\
(1991-2006)\end{array}$} & \multicolumn{2}{|c|}{ Differences from Base Period } & \multirow{2}{*}{$\begin{array}{l}\text { Base Period } \\
(1991-2006)\end{array}$} & \multicolumn{2}{|c|}{ Differences from Base Period } & \multirow{2}{*}{$\begin{array}{l}\text { Base Period } \\
(1991-2006)\end{array}$} & \multicolumn{2}{|c|}{ Differences from Base Period } \\
\hline & & $\begin{array}{l}\text { Crisis } \\
(2007-08)\end{array}$ & $\begin{array}{l}\text { Post-Crisis } \\
(2009-11)\end{array}$ & & $\begin{array}{l}\text { Crisis } \\
(2007-08)\end{array}$ & $\begin{array}{l}\text { Post-Crisis } \\
(2009-11)\end{array}$ & & $\begin{array}{l}\text { Crisis } \\
(2007-08)\end{array}$ & $\begin{array}{l}\text { Post-Crisis } \\
(2009-11)\end{array}$ \\
\hline Intercept & -0.06 & $-2.21 *$ & 0.04 & -0.03 & -1.71 & -0.08 & -0.03 & $-1.79 * *$ & -0.12 \\
\hline DV Lag & $0.05^{* *}$ & -0.19 & $-0.27 * * *$ & $0.07 * *$ & $-0.58 * * *$ & $-0.17 * *$ & 0.04 & $-0.33^{* *}$ & $-0.23 * * *$ \\
\hline$\triangle T B$ yield & $0.24 * * *$ & $-0.57 * * *$ & $-0.21 * * *$ & $0.27 * * *$ & $-0.58 * * *$ & -0.01 & $0.41 * * *$ & $-0.82 * * *$ & -0.17 \\
\hline$B Y C R$ & $12.73 * * *$ & 15.96 & $-11.69 * * *$ & $4.52 * *$ & 5.51 & $-4.73 * *$ & $2.95 * * *$ & -1.79 & $-2.69 * *$ \\
\hline$A Y C R$ & 0.38 & -1.45 & -0.15 & -0.33 & -5.25 & 0.78 & $-1.56^{*}$ & $5.32 * * *$ & 0.00 \\
\hline BYEND & $-7.88 * * *$ & -2.24 & $7.72 * * *$ & $-2.77 * * *$ & 1.01 & $2.85 * * *$ & -0.87 & -2.47 & 0.19 \\
\hline AYEND & $-2.35 * * *$ & -2.43 & 0.79 & $-1.71 * * *$ & -3.47 & 0.27 & -1.13 & $-9.83 * * *$ & 0.89 \\
\hline $\begin{array}{l}F \text {-stat. } \\
\text { Adj. } R^{2}\end{array}$ & \multicolumn{3}{|c|}{$\begin{array}{l}41.5 * * * \\
13.4 \%\end{array}$} & \multicolumn{3}{|c|}{$\begin{array}{c}32.3 * * * \\
10.7 \%\end{array}$} & \multicolumn{3}{|c|}{$\begin{array}{c}53.0 * * * \\
16.6 \% \\
\end{array}$} \\
\hline
\end{tabular}

Panel B. Eurodollar Rate Changes, 1991-2011, in bps.

\begin{tabular}{|c|c|c|c|c|c|c|c|c|c|}
\hline & \multicolumn{3}{|c|}{ 1-month } & \multicolumn{3}{|c|}{ 3-month } & \multicolumn{3}{|c|}{ 6-month } \\
\hline & \multirow{2}{*}{$\begin{array}{l}\text { Base Period } \\
(1991-2006)\end{array}$} & \multicolumn{2}{|c|}{ Differences from Base Period } & \multirow{2}{*}{$\begin{array}{l}\text { Base Period } \\
(1991-2006)\end{array}$} & \multicolumn{2}{|c|}{ Differences from Base Period } & \multirow{2}{*}{$\begin{array}{l}\text { Base Period } \\
(1991-2006)\end{array}$} & \multicolumn{2}{|c|}{ Differences from Base Period } \\
\hline & & $\begin{array}{l}\text { Crisis } \\
(2007-08) \\
\end{array}$ & $\begin{array}{l}\text { Post-Crisis } \\
(2009-11) \\
\end{array}$ & & $\begin{array}{l}\text { Crisis } \\
(2007-08)\end{array}$ & $\begin{array}{l}\text { Post-Crisis } \\
(2009-11)\end{array}$ & & $\begin{array}{l}\text { Crisis } \\
(2007-08)\end{array}$ & $\begin{array}{l}\text { Post-Crisis } \\
(2009-11)\end{array}$ \\
\hline Intercept & $-0.10 *$ & -1.48 & -0.02 & -0.05 & -0.92 & -0.13 & -0.05 & -0.69 & -0.20 \\
\hline DV Lag & $-0.10 * * *$ & 0.14 & -0.23 & $-0.08 * *$ & $0.43 * * *$ & 0.03 & $-0.04 *$ & $0.30 *$ & 0.02 \\
\hline$\triangle T B$ yield & $0.17 * * *$ & $-0.27 * *$ & $-0.39 *$ & $0.17 * * *$ & $-0.25 * * *$ & $-0.30 *$ & $0.22 * * *$ & $-0.34 * *$ & $-0.26 * *$ \\
\hline$B Y C R$ & $15.99 * * *$ & 18.65 & $-15.87 * * *$ & $5.49 * * *$ & 21.67 & $-5.32 * * *$ & $2.97 * * *$ & -0.89 & $-3.20 * * *$ \\
\hline$A Y C R$ & $1.76^{*}$ & -5.13 & -1.34 & -0.54 & -8.11 & 0.89 & -0.51 & -0.47 & 0.21 \\
\hline BYEND & $-7.54 * * *$ & -8.31 & $7.51 * * *$ & $-2.44 * * *$ & -5.04 & $2.54 * * *$ & $-1.86 * * *$ & 0.70 & $2.12 * * *$ \\
\hline AYEND & -2.03 & -1.95 & 4.60 & -1.07 & 1.12 & 1.20 & 0.22 & $-5.54 * *$ & 0.04 \\
\hline $\begin{array}{l}F \text {-stat. } \\
\text { Adj. } R^{2}\end{array}$ & \multicolumn{3}{|c|}{$\begin{array}{c}20.3 * * * \\
6.9 \% \\
\end{array}$} & \multicolumn{3}{|c|}{$\begin{array}{c}31.5 * * * \\
10.5 \% \\
\end{array}$} & \multicolumn{3}{|c|}{$\begin{array}{c}14.9 * * * \\
5.1 \%\end{array}$} \\
\hline
\end{tabular}


TABLE 2. Regression Results (continued).

Panel C. Financial CP Rate Changes, 1997-2011, in bps.

\begin{tabular}{|c|c|c|c|c|c|c|c|c|c|}
\hline & \multicolumn{3}{|c|}{ 1-month } & \multicolumn{3}{|c|}{ 2-month } & \multicolumn{3}{|c|}{ 3-month } \\
\hline & \multirow{2}{*}{$\begin{array}{l}\text { Base Period } \\
(1997-2006)\end{array}$} & \multicolumn{2}{|c|}{ Differences from Base Period } & \multirow{2}{*}{$\begin{array}{l}\text { Base Period } \\
(1997-2006)\end{array}$} & \multicolumn{2}{|c|}{ Differences from Base Period } & \multirow{2}{*}{$\begin{array}{l}\text { Base Period } \\
(1997-2006)\end{array}$} & \multicolumn{2}{|c|}{ Differences from Base Period } \\
\hline & & $\begin{array}{l}\text { Crisis } \\
(2007-08)\end{array}$ & $\begin{array}{l}\text { Post-Crisis } \\
(2009-11)\end{array}$ & & $\begin{array}{l}\text { Crisis } \\
(2007-08)\end{array}$ & $\begin{array}{l}\text { Post-Crisis } \\
(2009-11)\end{array}$ & & $\begin{array}{l}\text { Crisis } \\
\text { (2007-08) }\end{array}$ & $\begin{array}{l}\text { Post-Crisis } \\
(2009-11)\end{array}$ \\
\hline Intercept & -0.01 & -1.42 & -0.08 & 0.00 & -0.99 & -0.20 & 0.00 & -1.55 & -0.21 \\
\hline DV Lag & 0.09 & $-0.53 * * *$ & $-0.56 * * *$ & -0.02 & $-0.45 * * *$ & $-0.46 * * *$ & -0.05 & -0.28 & -0.16 \\
\hline$\Delta T B$ yield & $0.19 * * *$ & -0.05 & -0.19 & $0.18 * * *$ & -0.14 & -0.30 & $0.17 * * *$ & $-0.31 * *$ & -0.96 \\
\hline$B Y C R$ & 0.45 & -2.14 & 0.62 & -0.30 & -9.59 & 2.03 & -0.31 & $17.27 * * *$ & -0.15 \\
\hline$A Y C R$ & $5.26 *$ & -17.96 & $-5.35^{*}$ & 3.85 & 5.55 & -2.10 & 3.07 & $-6.96 * *$ & -3.21 \\
\hline BYEND & $-7.10 * *$ & -6.60 & 4.44 & $-4.86 * * *$ & $-21.88 * * *$ & 3.27 & $-3.95 * * *$ & -20.85 & 0.96 \\
\hline$A Y E N D$ & $2.17 *$ & 1.70 & 0.27 & 0.85 & 4.17 & 1.20 & 0.97 & $8.63 * *$ & $4.66 * *$ \\
\hline $\begin{array}{l}\text { F-stat. } \\
\text { Adj. } R^{2}\end{array}$ & \multicolumn{3}{|c|}{$\begin{array}{c}44.3 * * * \\
18.9 \%\end{array}$} & \multicolumn{3}{|c|}{$\begin{array}{c}51.4 * * * \\
21.6 \%\end{array}$} & \multicolumn{3}{|c|}{$\begin{array}{c}49.4 * * * \\
7.4 \%\end{array}$} \\
\hline
\end{tabular}

Panel D. BA Rate Changes, 1991-1999, in bps.

\begin{tabular}{|l|l|l|}
\hline & \multicolumn{1}{|c|}{ 3-month } & \multicolumn{1}{|c|}{ 6-month } \\
\hline Intercept & 0.00 & 0.02 \\
DV Lag & 0.01 & 0.01 \\
ATB yield & $0.36 * * *$ & $0.53 * * *$ \\
BYCR & $2.10 *$ & $2.45 * *$ \\
AYCR & 2.51 & -1.87 \\
BYEND & $-5.19 * *$ & $-2.87 * *$ \\
AYEND & $-3.48 *$ & -2.02 \\
& & \\
\hline F-stat. & $81.3 * * *$ & $147.4 * * *$ \\
Adj. $R^{2}$ & $17.6 \%$ & $28.1 \%$ \\
\hline
\end{tabular}


Note: Panels A, B, C report Equation (1) estimation output for changes in CD, ED, and Financial CP yields, respectively:

$$
\begin{aligned}
& \Delta \mathrm{R}_{\mathrm{t}}=\alpha_{0}+\alpha_{1}\left(\Delta \mathrm{R}_{\mathrm{t}-1}\right)+\alpha_{2}\left(\Delta \mathrm{TB}_{\mathrm{t}}\right)+\alpha_{3} \mathrm{BYCR}+\alpha_{4} \mathrm{AYCR}+\alpha_{5} \mathrm{BYEND}+\alpha_{6} \mathrm{AYEND} \\
& +\mathrm{b}_{0} \mathrm{Yrs} 0708+\mathrm{b}_{1}\left(\Delta \mathrm{R}_{\mathrm{t}-1}\right) \mathrm{Yrs0708}+\mathrm{b}_{2}\left(\Delta \mathrm{TB}_{\mathrm{t}}\right) \mathrm{Yrs} 0708+\mathrm{b}_{3}(\mathrm{BYCR}) \mathrm{Yrs} 0708 \\
& \text { + b4(AYCR)Yrs0708 + b5(BYEND)Yrs0708 + b6 (AYEND)Yrs0708 } \\
& +\mathrm{c}_{0} \operatorname{Yrs} 0911+\mathrm{c}_{1}\left(\Delta \mathrm{R}_{\mathrm{t}-1}\right) \operatorname{Yrs} 0911+\mathrm{c}_{2}\left(\Delta \mathrm{TB}_{\mathrm{t}}\right) \operatorname{Yrs} 0911+\mathrm{c}_{3}(\mathrm{BYCR}) \operatorname{Yrs} 0911 \\
& +\mathrm{c}_{4}(\mathrm{AYCR}) \text { Yrs0911 + } \mathrm{c}_{5}(\mathrm{BYEND}) \text { Yrs0911 + } \mathrm{c}_{6}\left(\text { AYEND)Yrs0911+ } \varepsilon_{\mathrm{t}}\right.
\end{aligned}
$$

Panel D reports the results for BA yields, which, due to data availability, do not cover the crisis period and thus involve only the first seven right-hand side variables from Equation (1).

*** significant at the $1 \%$ level.

** significant at the $5 \%$, level.

$*$ significant at the $10 \%$ level. 
TABLE 3. Mean Differences between Yields of Money Market Instruments before, during, and after the Crisis of 2007-2008.

\begin{tabular}{|c|c|c|c|c|c|c|c|c|c|}
\hline & \multicolumn{3}{|c|}{ 1-month } & \multicolumn{3}{|c|}{ 3-month } & \multicolumn{3}{|c|}{ 6-month } \\
\hline & $\begin{array}{c}\text { Base } \\
\text { Period, } \\
\text { before } \\
2007\end{array}$ & $\begin{array}{l}\text { Crisis, } \\
2007- \\
2008\end{array}$ & $\begin{array}{c}\text { Post- } \\
\text { Crisis, } \\
2009- \\
2011\end{array}$ & $\begin{array}{c}\text { Base } \\
\text { Period, } \\
\text { before } \\
2007\end{array}$ & $\begin{array}{l}\text { Crisis, } \\
2007- \\
2008\end{array}$ & $\begin{array}{l}\text { Post- } \\
\text { Crisis, } \\
2009- \\
2011\end{array}$ & $\begin{array}{c}\text { Base } \\
\text { Period, } \\
\text { before } \\
2007\end{array}$ & $\begin{array}{c}\text { Crisis, } \\
2007- \\
2008\end{array}$ & $\begin{array}{c}\text { Post- } \\
\text { Crisis, } \\
2009- \\
2011\end{array}$ \\
\hline CD yield,\% & 4.208 & 4.008 & 0.246 & 4.272 & 4.140 & 0.382 & 4.371 & 4.200 & 0.567 \\
\hline ED yield, $\%$ & 4.187 & 4.173 & 0.412 & 4.271 & 4.326 & 0.621 & 4.373 & 4.383 & 0.875 \\
\hline difference, bps & 2.1 & $16.5^{*}$ & $16.6^{* * *}$ & 0.1 & $18.6^{* * *}$ & $23.9 * * *$ & 0.2 & $18.3^{* * *}$ & $30.8 * * *$ \\
\hline CD vield. \% & 3015 & 4018 & 0246 & 3077 & 4259 & 0375 & & & \\
\hline Financial CP yield, $\%$ & 3.860 & 3.767 & 0.196 & 3.897 & 4.074 & 0.295 & & & \\
\hline difference, bps & 5.4 & $25.1 * * *$ & $5.1 * * *$ & 7.4 & $18.5^{* *}$ & $8.0 * * *$ & & & \\
\hline FD vield \% & 3806 & 4181 & 0411 & 3065 & 4404 & 0611 & & & \\
\hline Financial CP yield, $\%$ & 3.861 & 3.765 & 0.196 & 3.898 & 4.072 & 0.296 & & & \\
\hline difference, bps & 3.4 & $41.5 * * *$ & $21.6 * * *$ & 8.7 & $33.2 * * *$ & $31.5 * * *$ & & & \\
\hline
\end{tabular}

Note: The mean equality tests were run on common samples (i.e., both series must have available data on a given day). This is a reason for discrepancies in the means of the same series in different pairs. CD and ED data are available from 1991 through 2011, CP data are available from 1997 through 2011. The p-values (not reported) are based on twotailed t-tests.

*** significant at the $1 \%$ level.

** significant at the $5 \%$, level.

* significant at the $10 \%$ level. 
Figure I. Average Intrayear Spreads between Yields of Private-issue Securities and T-bills.

A. Average Intrayear Spreads between CD and T-bill yields, 1991-2011.

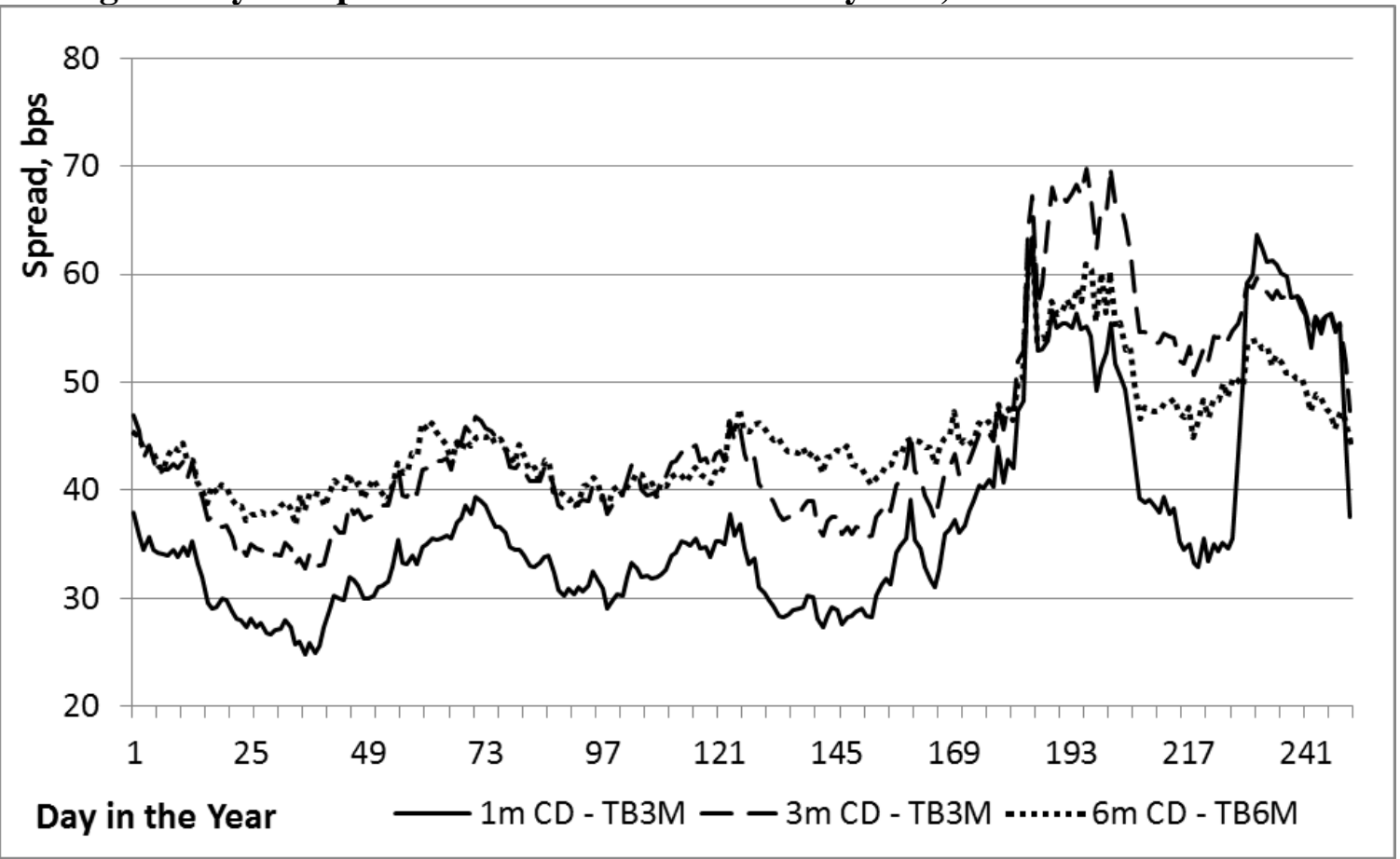

B. Average Intrayear Spreads between Eurodollar Deposit and T-bill Yields, 1991-2011.

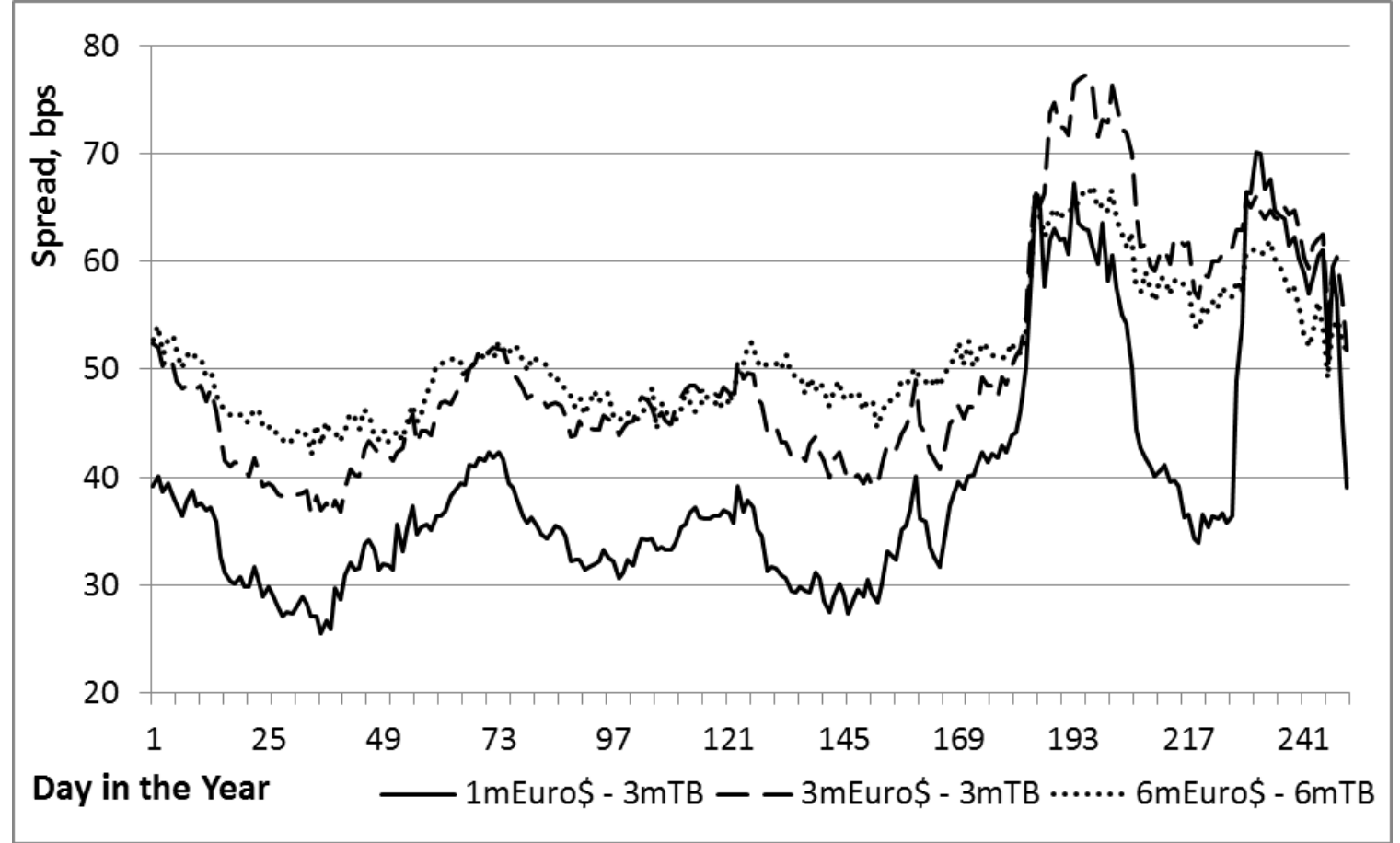


Figure I. Average Intrayear Spreads between Yields of Private-issue Securities and T-bills (continued).

C. Average Intrayear Spreads between Financial Commercial Paper and T-bill Yields, 1997-2011.

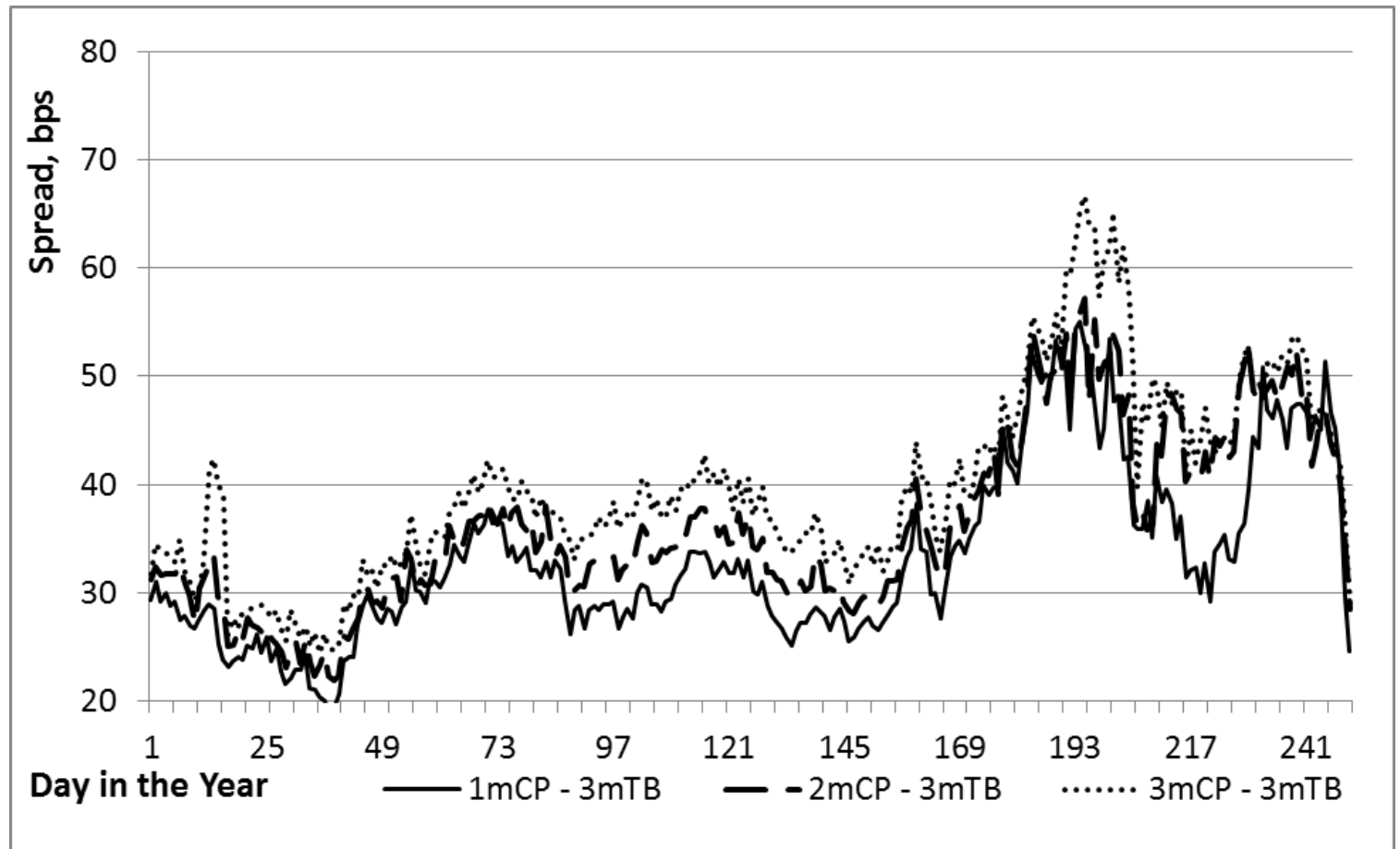

D. Average Intrayear Spreads between Banker's Acceptance and T-bill Yields, 19911999.

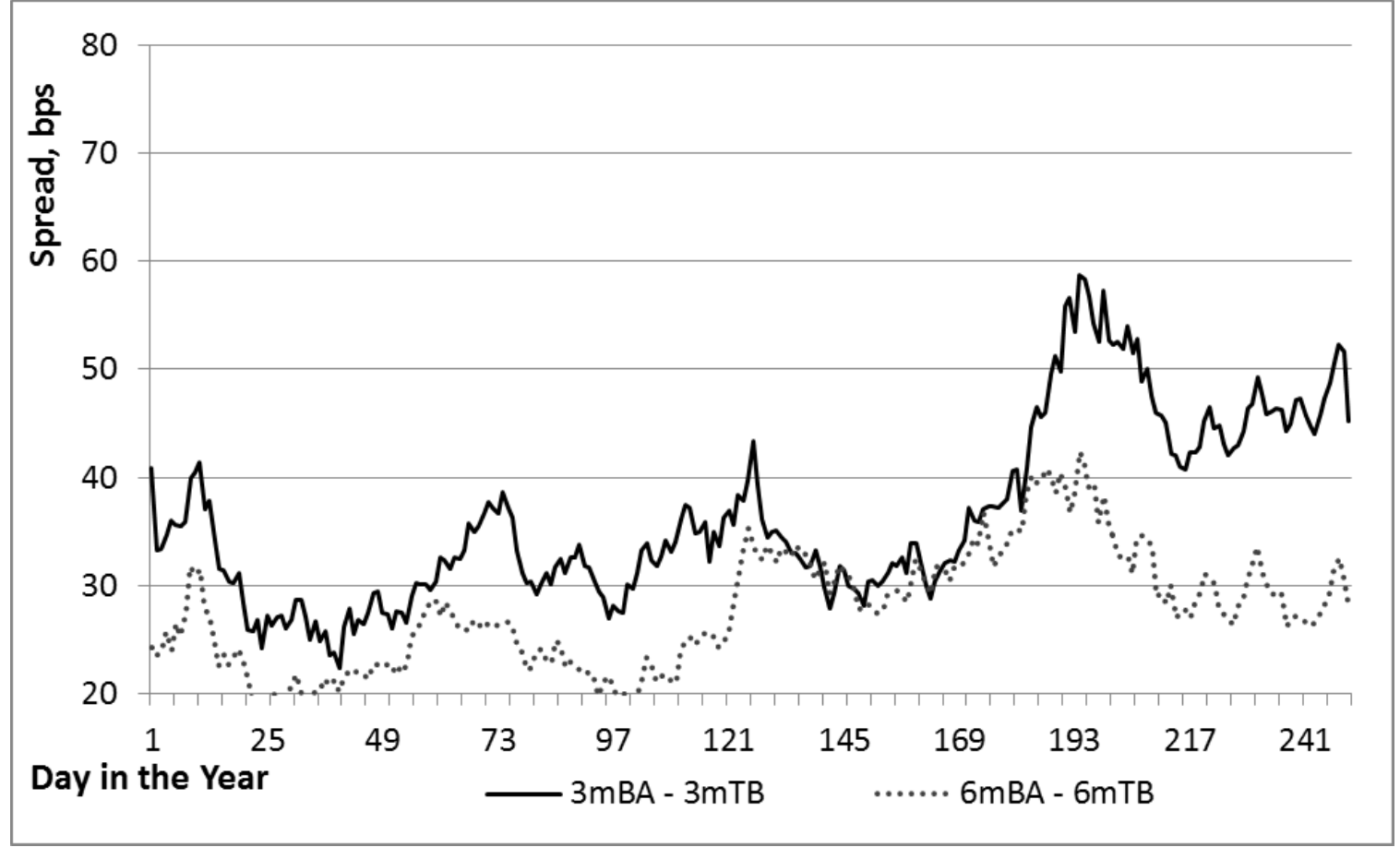


Note: To construct the average intrayear spread plots, some low-volatility observations have been deleted or inserted to ensure that every year has exactly 250 days. For each day from 1 to 250 , spreads between the yields of the studied private instruments and T-bill rates were calculated and then averaged for all years in the sample. E.g., the spreads on Day 15 of every year are used to compute the average intrayer spread for Day 15. 
Figure II. Three-month CD, ED, CP, and T-bill Yields, 2006-2011.

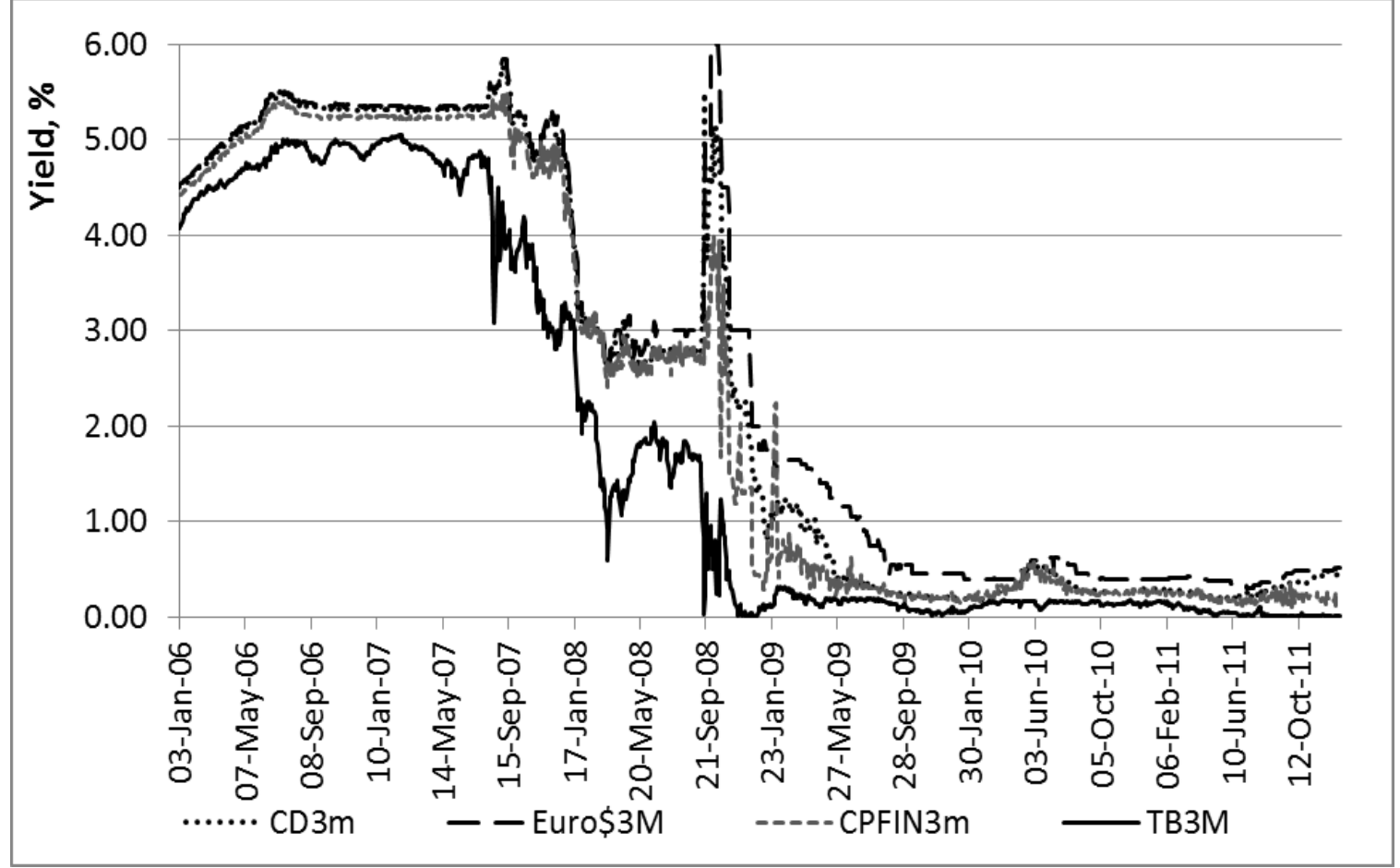

